ENTOMOLOGY

\title{
Host Range, Life Aspects and Mode of Damage of Brinjal Shoot and Fruit Borer (Leucinodes orbonalis Guenee) on Brinjal:
} A Review

\author{
Lipsa Dash*, V Rama Lakshmi and Deepayan Padhy
}

Department of Entomology, MSSSoA, CUTM, Paralakhemundi, Odisha, India

*Corresponding author: lipsa.bckv@gmail.com (ORCID ID: 0000-0003-3335-6153)

Paper No. 820

Received: 06-11-2019

Revised: 10-01-2020

Accepted: $30-02-2020$

\begin{abstract}
Brinjal (Eggplant) Solanum melongena Linnaeus is the most important vegetable of hot and humid climates. A wide range of essential biochemicals and minerals belongs to brinjal. It is a fairly good source of iron, calcium, phosphorous, potassium and vitamin B group. Brinjal Shoot and Fruit Borer Leucinodes orbonalis Guenee is the major infectious insect causing a great damage to plants. BSFB generally depends on brinjal but it may infest other solanaceous field crops and may be on wild hosts. The insect has been reported a number of crops such as S. tuberosum (potato), S. lycopersicum and some other Solanaceous crops. The damage by this borer starts at seedling stage and continues till the last harvest of fruits. Egg-laying occurs during night and incubation period ranges from 3-8 days depending of environmental conditions. Larval period completes in 12-22 days depending upon environmental situations and passes through five instars. Full grown larvae pupate into the soil or under plant debris and dropped dead shoots. Adult of BSFB is a whitish moth which hides during day time and activates from dusk to perform various activities like mating oviposition. Larvae bore into fruits and shoots and in younger plants, caterpillars drill into midrib of large leaves. At the time of maturity, damage of the insect on fruits causes a serious loss in yield.

\section{Highlights}

- BSFB generally depends on brinjal but it may infest other solanaceous field crops and may be on wild hosts. The insect has been reported a number of crops such as S. tuberosum (potato), S. lycopersicum and some other Solanaceous crops.

(0 Fecundity varies from $80-253$ and the whole lifecycle is completed in 34-59 days. The damage by this borer starts at seedling stage and continues till the last harvest of fruits. Damage to the fruits at the time of maturity causes serious yield loss.
\end{abstract}

Keywords: Brinjal, Shoot and fruit borer, Lepidoptera

Eggplant, Solanum melongena Linnaeus is a standout amongst the most vital vegetables in South and South-East Asia (Thapa 2010). It is a prominent vegetable developed in territories having a hot humid agroclimatic zone (Hanson et al. 2006) like that happening in southeast Asia (Thapa 2010) where it is the most regularly consumed solanaceous vegetable (Kantharajha and Golegaonkar 2004). It is a fairly good source of iron, calcium, phosphorous, potassium and vitamin B group. Its fresh weight is composed of $92.7 \%$ moisture, $1.4 \%$ protein, $1.3 \%$ fibre, $0.3 \%$ fat, $0.3 \%$ minerals, and the remaining $4 \%$ consists of various carbohydrates and vitamins (A and C) (Aykroyd 1963). Apart from its nutritional value, eggplant has also been used in traditional medicinal purpose. For example, tissue extract have been used for treatment of asthma, bronchitis, cholera and dysuria; fruits of white brinjal are beneficial for diabetic patient (Choudhury 1976a); fruits and leaves are beneficial in lowering blood cholesterol. Brinjal fruits are widely used in various culinary preparations viz., sliced bhaji, stuffed curry, bharta, chatni, pickles etc. It has also got much potential as raw material in pickle making and dehydration industries (Singh et al. 1963).

Twenty-eight species of insect pests and mites have been reported to be associated with brinjal, of which brinjal shoot and fruit borer (Leucinodes orbonalis), 
Jassids (Amrasca biguttula and A. devastans), Hadda beetle (Henosepilachna vigintioctpuntata), Aphids (Aphis gossypi), White fly (Bemisia tabaci) are found to be abundant on this crop ( Patial and Mehta, 2008). Among these the brinjal shoot and fruit borer has been reported to be the serious pest which reduces the crop yield up to $60-70 \%$ and inflicts the colossal loss in production (Singh and Nath 2010).

Eggplant shoot and fruit borer, Leucinodes orbonalis Guenee is the key pest of egg plant (Latifetal., 2010; Chakraborti and Sarkar 2011; Saimandir and Gopal 2012) incurring sizeable damage in nearly all the eggplant developing regions (Dutta et al. 2011). Among the elements in charge of low yield of brinjal, brinjal shoot and fruit borer (BSFB), Leucinodes orbonalis Guen. is the most genuine one, which may cause $100 \%$ damage if no control measures are connected (Rahman 2007).

\section{View point}

A broad audit was done to gather applicable information with conference of diary articles, procedures, yearly reports, theory works and so forth covering fundamentally.

\section{Taxonomy}

The ordered position as indicated by CABI (2007) is given as:

$\begin{array}{ll}\text { Phylum } & : \text { Arthropoda } \\ \text { Class } & : \text { Insecta } \\ \text { Order } & : \text { Lepidoptera } \\ \text { Family } & : \text { Crambidae } \\ \text { Genus } & : \text { Leucinodes } \\ \text { Species } & : \text { orbonali } \\ \text { Scientific name } & \text { Leucinodes orbonalis Guenee }\end{array}$

\section{Host range}

L.orbonalis Guenee is essentially monophagous, encouraging mainly on eggplant; in any case, different plants having a place with family Solanaceae are accounted for to be hosts of this pest. Besides brinjal, it was also found to attack shoots and fruits of tomato (Das and Patnaik 1970), potato (Solarium tuberosum L.), green peas (Pisum sativum L.) and Solanum torvum Swartz (Hill 1987). Other wild species of Solanum are also attacked by this pest (Karim 1994). Lsahaquc and Chaudhury (1983) reported Solanum nigrum, S. indicum, S. torvum, S.myriacanthum and potato as alternate host plants of BSFB in Assam. Das and Patnaik (1970) studied that Leucinodes orbonalis Guenee, a serious pest of brinjal (Solanum melongena), was also observed to bore into the shoots and fruits of tomato in Bhubaneswar, India. The insect was found to be able to complete its development on tomato and also on the weed S. nigrum, but moths that had been reared on the latter were smaller and laid fewer eggs than those reared on tomato or brinjal.

\section{Life cycle}

Like different individuals from the order Lepidoptera, L. orbonalis experiences four development stages: egg, Larva, pupa and adult. The larval period is the longest, followed by pupal and egg period.

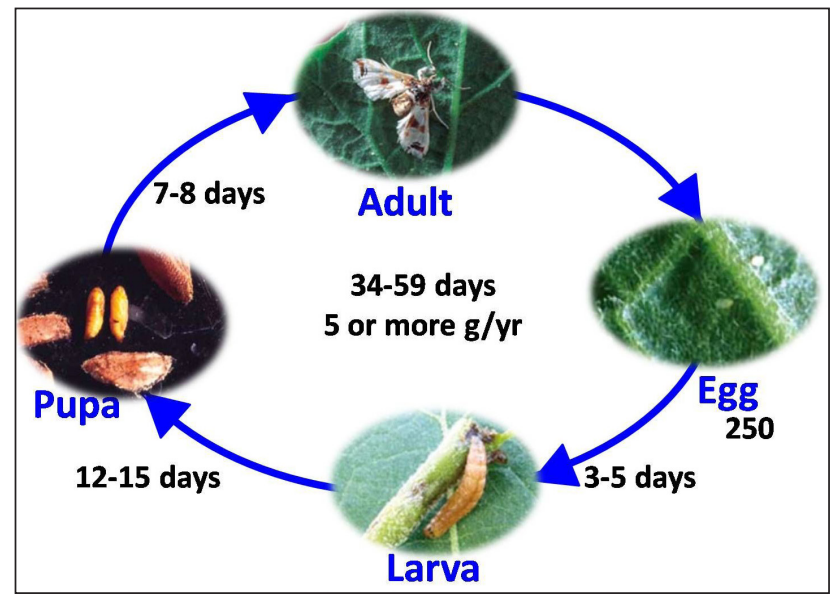

Fig. 1: Life cycle of brinjal shoot and fruit borer

\section{Egg}

Oviposition takes place during the night and eggs are laid singly on the lower surface of the young leaves, green stems, flower buds, or calyces of the fruits and number of eggs laid by female varies from 80 to 253 (Taley et al. 1984; Alpuerto 1994), however, reported as high as 260 (FAO, 2003). They are flattened, elliptical with $0.5 \mathrm{~mm}$ in diameter and colour is creamy-white but change to red before hatching (Alam et al. 2006).

\section{Larva}

The larval period lasts 12-15 days during summer and 14 - 22 days during winter season (Rahman et al. 2006). Larvae pass through at least five instars (Atwal 1976) and there are reports of the existence of six 
larval instars (Baang and Corey 1991; FAO 2003). First instars are found in flower buds and flowers, second instars in all susceptible plant parts, third and fourth instars in shoots and fruits and fifth instars mostly in fruits (Rahman et al. 2006). BSFB damage is caused by the larva which feeds inside the fruit and at the same time leave large exit holes when leaving to pupate, reducing the market value of the fruits and rendering them unfit for human consumption (Alam et al. 2003).

\section{Pupa}

The full- grown larvae come out of the infested shoots and fruits and pupate in the dried shoots and leaves or in plant debris fallen on the ground within tough silken cocoons. There were evidences of presence of cocoons at soil depths of 1 to $3 \mathrm{~cm}$ (Alam et al., 2003). They pupate on the surface they touch first (FAO, 2003). The pupal period lasts 6 to 17 days depending upon temperature (Alam et al. 2003).

\section{Adult}

The adult is a small white moth with 40-segmented antennae (Sexena 1965) and having spots on fore wings of 20 to $22 \mathrm{~mm}$ spread. It gains full maturity in 10 to 14 days. Longevity of adults lasts 1.5 to 2.4 days for males and 2.0 to 3.9 days for females. The pre-oviposition and oviposition periods range 1.2 to 2.1 and 1.4 to 2.9 days, respectively (Mehto et al. 1983). The adult male dies after mating and the female moth dies after laying eggs (Kar et al. 1995). The overall life cycle completes in 22 to 55 days. It gives rise five generations a year and is active throughout the year.

FAO (2003) showed the effect of climatic conditions in the life cycle of the L. orbonalis in eggplant. $L$. orbonalisis active in summer months, especially during the rainy season and less active from November to February. Peak populations are often reported in June-August.

\section{Nature of Damage}

L. orbonalis attacks mostly on flowering, fruiting and vegetative growing stage on fruits/pods, growing points and inflorescence (CABI, 2007). The higher percent of the larvae was in fruits followed by shoots, flowers, flower buds and midrib of leaves (Alpuruto 1994). In young plants, caterpillars are accounted for to exhaust inside petioles and midribs of extensive leaves (Butani and Jotwani 1984; Alpureto 1994; AVRDC. 1998) along these lines shrivelling, dropoff and shrink of the young shoots occur prompting delay on shoot development, decrease on yield and yield parameter. The caterpillars of Leucinodes orbonalis drill into the developing points of young tender shoots and a wilted drooping shoots a run of the mall manifestation, which at last shrivels away. The fruiting beads droop down while the fruits indicate round openings, which are the leave gaps of the caterpillar (Peshwani and Lal 1964).

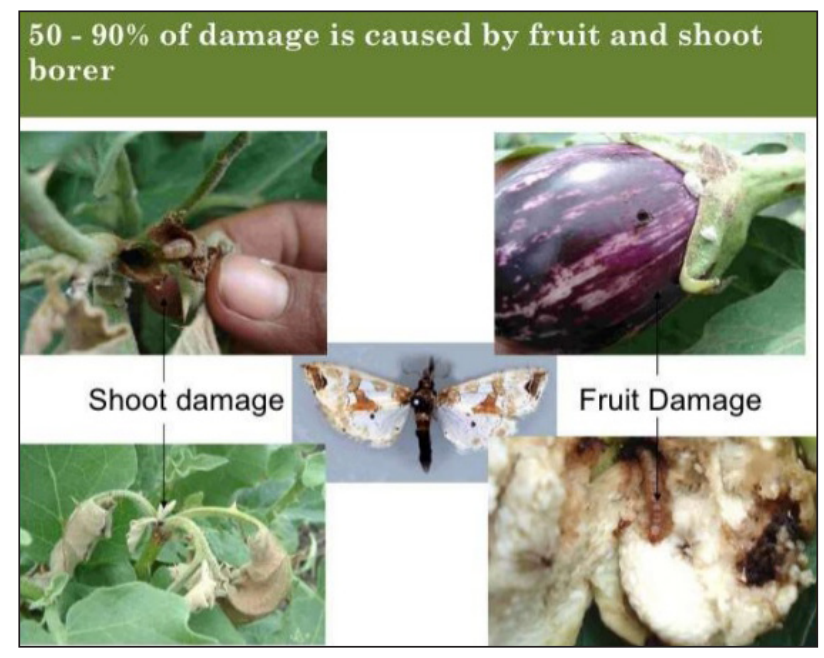

Fig. 2

At vegetative stage, the recently brought forth larvae bore in to petioles and midrib of huge leaves and young delicate shoots they feed up on the inward tissue causing the shoot hung down and wilted at the regenerative stage. The larvae like to drill into blossom buds and furthermore go into the plagued fruits through the calyx.

Damage to the fruits, especially in harvest time, is exceptionally extreme and the entire yield can be annihilated (Atwal 1976). Ghosh and Senapati (2009) found that this pest causes the most destruction and is most dynamic amid the late spring months, i.e., from May to August. It turns out to be less dynamic amid the winter months, especially in December and January. Patel et al. (1988) discovered shoot and fruit damage in brinjal by BSFB was higher in May transplanted (spring) crops than that in July and September transplanted (fall) crops. The misfortunes caused by insect change from season to 
season since direct temperature and high moisture support the population development of brinjal shoot and fruit borer (Shukla and Khatri 2010), (Bhushan et al. 2011). Watching the drilling openings, the pervaded fruits can be distinguished without much of a stretch. Furthermore, the dull shaded excreta can be seen without much of a stretch to the opening of pervaded fruits.

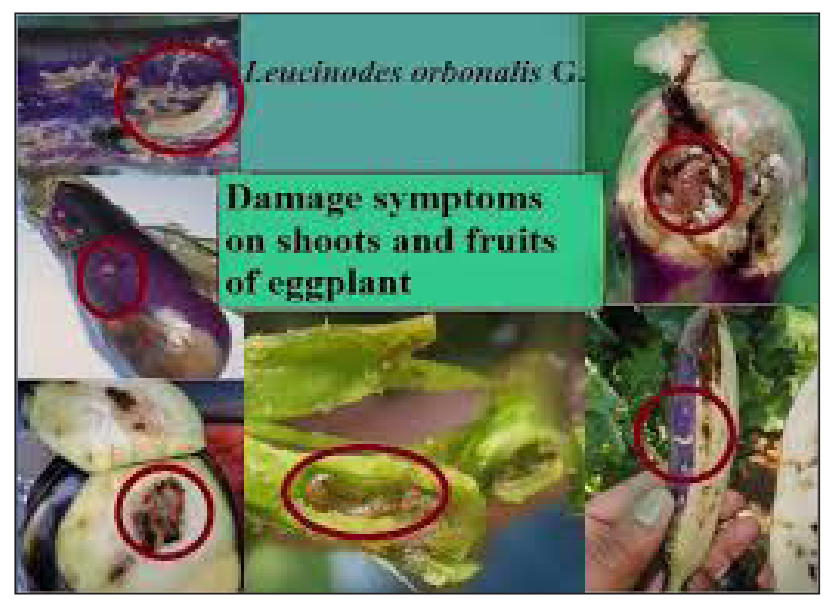

Fig. 3

\section{CONCLUSION}

Likewise, other lepidopterans only the larval stage of $L$. orbonalis is the damage causing stage. As discussed above, hot and humid climate favours the pest population growth. In severe cases, a single part of the plant cannot escape from being damaged. Flowers, shoots, fruits, inflorescence and developing structures are consumed especially fruits which are not remain edible after pest infestation. In severe cases, a single part of the plant cannot escape from being damaged. Flowers, shoots, fruits, inflorescence and developing structures are consumed especially fruits which are not remain edible after pest infestation. Not only brinjal, L. orbonalis is found on a wide range of hosts like most of the solanaceous crops.

\section{REFERENCES}

Alam, S.N., Hossain, M.I., Rouf, F.M.A., Jhala, R.C., Patel, M.G. and Rath, L.K. et al. 2006. Implementation and promotion of an IPM strategy for control of eggplant fruit and shoot borer in South Asia. Technical Bulletin. AVRDC publication AVRDC - The World Vegetable Center, Shanhua, Taiwan.

Alam, S.N., Rashid, M.A., Rouf, F.M.A., Jhala, R.C. and Patel, J.R. et al. 2003. Development of an integrated pest management strategy for eggplant fruit and shoot borer in
South Asia. AVRDC-the World Vegetable Center Technical Bulletin No. 28. AVRDC Publication No, 03-548, Shanhua, Taiwan, pp. 56.

Alpuerto, A.B. 1994. Ecological studies and management of brinjal fruit and shoot borer, Leucinodes orbonalis Guenee. Indian Journal of Agricultural Sciences, 52(6): 391-395.

Atwal, A.S. 1976. Agricultural pests of India and Southeast Asia. Kalyani Publishers. New Delhi, India, pp. 529.

AVRDC. 1995. AVRDC report 1994. Asian Vegetable Research and Development Centre, Shanhua, Taiwan, pp. 520.

Aykroyd, W.R. 1963. The nutritive value of Indian Foods and the planning of satisfactory diets. IMCR, Special Report. Series No. 42.

Baang, L.A. and Corey, F.M. 1991. Life history of an eggplant fruit and shoot borer, Leucinodes orbonalis (Guenee) (Lepidoptera: Pyralidae). Chiang Mai University Journal of Science, 4(1): 45-61.

Bhushan, S., Chaurasia, H.K. and Shanker, R. 2011. Efficacy and economics of pest management modules against brinjal shoot and fruit borer (Leucinodes orbonalis). The Bioscan., 6(4): 639-642.

Butani, D.K. and Jotwani, M.G. 1984. Insects in vegetables. Periodical, Expert Book Agency. New Delhi, India, pp. 356.

CABI. 2007. Crop protection compendium. CAB International (Available at: http://www. cabicompendium.org/cpc Retrieved on March 15, 2012).

Chakraborty, S. and Sarkar, P.K. 2011. Management of Leucinodes orbonalis Guenee on eggplant during the rainy season in India. Journal of Plant Protection Research, 51(4): 325-328.

Choudhary, B. 1976a. Vegetables (4 $4^{\text {th }}$ edn.), National Book Trust, New Delhi, pp. 50-58.

Dutta, P., Singha, A.K., Das, P. and Kalita, S. 2011. Management of brinjal fruit and shoot borer, Leucinodes orbanalis Guenee in agro-ecological condition of West Tripura. Scholarly journal of Agricultural Science, 1(2): 16- 19.

Ghosh, S.K. and Senapati, S.K. 2009. Seasonal fluctuation in the population of Leucinodes orbonalis Guen. in the subhimalayan region of West Bengal, India and its control on eggplant (Solanum melongena L.). Precision Agriculture, 10: 443449 .

Hanson, P.M., Yang, R.Y., Tsou, S.C.S., Ledesma, D., Engle, L. and Lee, T.C. 2006. Diversity of eggplant (Solanum melongena) for superoxide scavenging activity, total phenolics and ascorbic acid. Journal of Food Composition and Analysis, 19(6-7): 594-600.

Kar, A.C. and Khan, M.A. 1985. Homestead bio-intensive gardening and agroforestry. A technical reference manual. LIFT Project, CARE Bangladesh.

Latif, M.A., Rahman, M.M. and Alam, M.Z. 2010. Efficacy of nine insecticides against shoot and fruit borer, Leucinodes orbonalis Guenee (Lepidoptera: Pyralidae) in eggplant. Journal of Pest Science, 5(4): 456-459. 
Mehto, D.N. and Lall, B.S. 1981. Comparative susceptibility of different brinjal cultivars against brinjal fruit and shoot borer. Indian Journal of Entomology, 43(1): 108- 109.

Patel, J.R., Korat, D.M. and Patel, V.B. 1988. Incidence of shoot and fruit borer (Leucinodes orbonalis Guen.) and its effect on yield in brinjal. Indian Journal of Plant Protection, 16: 143-145.

Rahman, M.M. 2006. Vegetable IPM in Bangladesh. In: Radcliffe EB, Hutchison WD (eds) Radcliffe's IPM world textbook.

Rahman, M.M. 2007. Vegetables 1PM in Bangladesh. In: Redcliffe's 1PM World Textbook, University of Minnesota, pp. 457-462.

Saimandir, J. and Gopal, M. 2012. Evaluation of synthetic and natural insecticides for the management of insect pest control of eggplant (Solanum melongena L.) and Pesticide Residue Dissipation Pattern. American Journal of Plant Sciences, 3(2): 214-227.
Saxena, P.N. 1965. The life history and biology of Leucinodes orbonalis Guen. Journal of Zoological Society of India, 17(12): 64-70.

Shukla, A. and Khatri, S.N. 2010. Incidence and abundance of brinjal shoot and fruit borer Leucinodes orbonalis Guenee. The Bioscan., 5(2): 305-308.

Singh, S.P. and Nath, P. 2010. Cultural and biophysical management of brinjal shoot and fruit borer (Leucinodes orbonalis). A biannual new letter of the (CIPS) in corporation with the (IRAC) and (WRCC-60), pp.42-43.

Taley, Y.M., Nighut, U.S. and Rajurkar, B.S. 1984. Bionomics of brinjal fruit and shoot borer, (Leucinodes orbonalis Guenee). Punjabrao Krishi Vidyapeeth Research Journal, 8(1): 29-39.

Thapa, R.B. 2010. Integrated management of brinjal fruit and shoot borer, Leucinodes orbonalis Guen: An overview. Journal of Institute of Agriculture and Animal Science, 30(32): $1-16$. 
